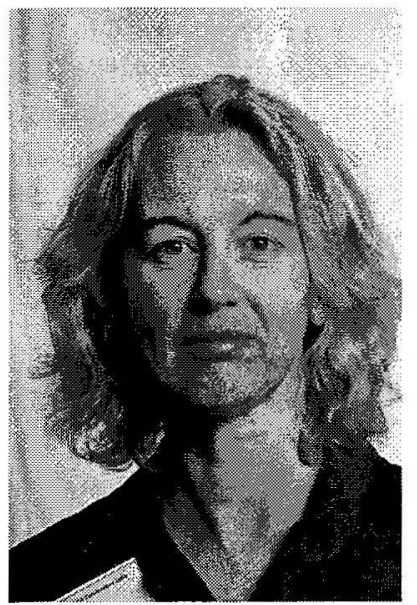

\title{
GENDER AND MANAGERIAL ATTAINMENT IN THE NEW ZEALAND PUBLIC SECTOR
}

\author{
Kerry Brown and Stacy Ridge \\ School of Management \\ QUT \\ Brisbane Australia
}

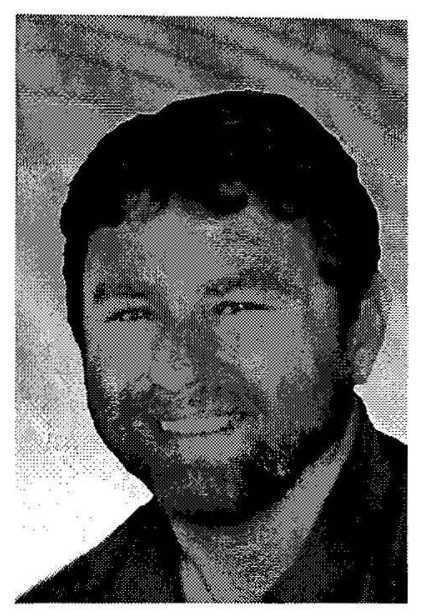

\begin{abstract}
Public sector equal employment opportunity (EEO) legislation was introduced to encourage greater diversity of representation throughout all areas of public sector employment. It has been noted that steady progress has been achieved with implementing legislated public sector EEO policies and programs to fulfil the aim of increasing the representation of EEO. However, despite the gains delivered through equity legislation and policies, there remain areas of gender differences in the public sector labour market. This research utilised EEO and employment data to analyze patterns of career progression and employment profiles in relation to public sector employees. The study examined the effects of gender segregation on careers and employment for males and females in both male dominated and female dominated public sector agencies. The findings confirm the general trend for improvements in the participation of women in the New Zealand public sector. However, there are areas that are shown to warrant attention. First, for women in male dominated agencies, the findings indicate that their representation is stable and static with poor outcomes. Second, in relation to women in female dominated agencies, results show an overall improvement in every job category. The final research area investigated the differences between male dominated and female dominated agencies. Agency characteristics identified in the research showed that all agencies were highly female dominated in the clerical classifications but male dominated agencies have significant overrepresentation of males in professional and managerial categories. Overall, the numbers of women in management and their progression through the levels of management remains problematic.
\end{abstract}

\section{Introduction}

Public sector equal employment opportunity (EEO) legislation was introduced to encourage greater diversity of representation throughout all areas of public sector employment. It has been noted that steady progress has been achieved with implementing legislated public sector EEO policies and programs to fulfil the aim of increasing the representation of EEO groups in the New Zealand public sector (Boston, Martin, Pallot and Walsh, 1996). However, despite the gains delivered through equity legislation and policies, there remain areas of gender differences in public sector employment.

The aim of the research was to gather employment data to examine and analyse management and classification type in the New Zealand public sector focusing specifically on career progression and management composition in those agencies that were dominated by one gender. The program of research was to determine those public sector agencies that were gender segregated and to analyse whether there were significant gender differences in managerial attainment, classification levels and career progression.
The paper is divided into three sections. The first section examines changes to the public sector to determine whether the 'New Zealand model' of restructuring and reform may have shaped an agenda that influenced employment outcomes in relation to gender. The second part reviews gender segregation and contextualises it within the public sector environment. The final section further develops the analysis by examining the extent of gender segregation in the New Zealand public sector. The proposition that gender segregation will have differential effects for males in female dominated agencies and females in male dominated agencies will be tested. Wajcman's (1998) contention that management is identified as a male sphere of activity and as such poses a considerable impediment to women aspiring to, and attaining, management positions is also investigated.

\section{Public sector reform and...gender?}

The public sector in New Zealand is argued to have undertaken a 'more radical' reform and restructuring agenda than other developed countries and this characteristic set it apart from the prevailing New Public Management (NPM) model that sought efficiency and a 
results-oriented managerial approach (Gregory, 1999). Quiggan (1998) argues that the model of reform was 'faster and more comprehensive' in New Zealand as a result of a lack of institutional barriers to the government restructuring program. Wallis and Dollery (2001) argue that the form of NPM adopted in New Zealand should be conceptualised as contractualism derived from an emphasis on delivering government services through contractual relationships between different arms of government, between funders and regulators and between purchasers and providers and, driven from the top down. These factors were significant in making the public sector amenable to a 'blitzkrieg approach' of implementing liberal free-market reforms based on an ideology of market-driven transactions in place of direct government service provision (Quiggan, 1998, Gregory, 1999). The changes had far-reaching consequences for public management and importantly, public employment.

The public sector operated traditionally on bureaucratic processes and procedures within a hierarchical structure and public employment offered a standardised set of policies and practices within a career service. The characteristics of NPM were adapted to bring an end to the notion of a career service through wide scale central government changes to allow almost unfettered departmental authority and autonomy in employment matters (Gregory, 1999). Following the reform begun in the 1980s, Gregory (1999) states that the public sector experienced a decline in numbers from 80,000 employees to only around 35,000 in the mid 1990s. This is partly explained by the core public service being pared back to exclude agencies such as health and education. The State Owned Enterprise Act 1986 translated government agencies to trading enterprises, setting these up as commercial entities and shifting activities out of the core public sector (Schwatrz, 1994).

The labour market policies aligned with the managerialist model signalled a dramatic shift in public sector wage and conditions setting and bargaining. Managerial discretion to recruit and terminate employment and, to determine individual pay rates was argued to put the public sector on par with the private sector and with this approach came an enforcement of 'private-sector-style wage disciplines' on public sector employees (Schwartz, 1994). The 1988 State Sector Act built on the 1987 Labour Relations Act in which deregulation of employment conditions was argued to have eroded notions of collectivist bargaining principles and led into the union-decimating Employment Contracts Act 1991 based on individual employment contracts (Quiggan, 1998).

Gregory (1999, p.68) suggests that the more flexible bargaining and industrial situation led to the 'seemingly exorbitant' salaries paid to senior managers. While some higher-ranking managers were able to negotiate superior individual salaries and improved conditions, it may be that many other public sector employees were vulnerable to the vagaries of an unregulated system and an inability to negotiate favourable bargaining outcomes. A shift to managerialism permitted broad discretion in employing and remuneration policies and in this way, may have resulted in disparity in outcomes for public sector employees. It was argued (Walsh, 1998) that reductions in employment conditions were consistent with the NPM model although overall the effect was not as significant as an adherence to liberal market ideology would suggest.

The resultant effect on public sector employment appears mixed, however. Walsh (1998) suggests that while changes have occurred in public sector conditions and managers have been able to garner significant salary increases there has also been stability in the system. This major reform agenda coincided with the introduction of EEO into the public sector. There was concern that the aims and objectives of EEO and NPM may be oppositional. At issue was whether the NPM model based on corporate management principles and practices with a focus on efficiency and the 'bottom line' could sustain an engagement with equity considerations (Wanna, Weller and O'Faircheallaigh, 1992). An agenda for NPM reform could expose programs such as EEO to utilitarian performance measures that rely on program outcomes rather than other qualitative measures of performance, or indeed, from the perspective of social justice or quality of working life issues (Sawer, 1999, Yeatman, 1993).

It was argued that the shift in advocating for employment equity on social justice grounds to that of the "business case' of negotiating equity measures in terms of promoting efficiency allowed a more strategic positioning of the equity agenda in a managerialist environment (Boston et al, 1996). Kramar (1995) contended that EEO could be articulated to a managerialist approach as EEO programs promoted efficiency as well as equity and social change. The State Services Commission of New Zealand (SSC, 1992 cited in Boston et al, 1996) stated that EEO is 'essential to the practice of good human resource management'. In eschewing a rights and social justice basis on which to argue and negotiate EEO, the public sector equity agenda aligned with NPM practices and principles. However, it may also be the case that the equity agenda is capable of being strategically realigned according to the tactical calculations of women in decision-making and policy-making areas of the public sector (Gardner and Palmer, 1997, van Acker, 2001).

Public sector equal employment opportunity has been implemented through a mix of legislative imperative and organizational initiatives to deal with particular areas of employment inequality (Brown, 1997). While public sector agencies are required legislatively to give attention to implementing EEO programs, allocating resources both human and financial and, considering the equity implications of broader public policies, there is a large amount of diversity in the way EEO polices and programs are implemented and undertaken. Consequently there is also wide variation in achieving improved employment and career outcomes. Public sector restructuring to devolve greater responsibility to managers in the New Zealand public sector also gave greater responsibility to manage EEO within individual 
agencies (Boston et al, 1996, Shick, 1996 cited in Wallis and Dollery, 2001). Whether this arrangement translates into differential access to equity measures and agency outcomes or whether the public sector-wide effects of a relatively stable set of employment conditions and policy instruments establish better overall gender equity outcomes is examined.

\section{Public sector employment outcomes and gender segregation}

Employment equity remains a salient issue in relation to public employment, particularly in light of the extent of transformational reforms to the public sector. However, the public sector is argued to establish enhanced prospects for women to achieve career progression and move through a career path to senior management ranks.

In a comparative study of seven countries, Gornick and Jacobs (1998) found that women fared better in public sector employment than private sector employment as more professional, technical and managerial employment opportunities were available for women. A comparison of private and public sector wage relativities between men and women in the UK found that the public sector salaries were pivotal to increasing women's wage relativity to that of men's wages and reasons for this favourable outcome centred on the centralised pay setting arrangements in the public sector (Grimshaw, 2000). A study by Hoffnar and Greene (1996) showed that while there was an earnings gap between male and female workers, this gap was not as significant in relation to the public sector workforce. The influence of the public sector's employing policies and regulatory regime has been significant in improving women's employment and career opportunities. However, any changes to the public sector through restructuring and reform may then be particularly deleterious for women and result in rolling back important early gains made in the areas of employment opportunity and pay equity.

Gornick and Jacobs (1998) suggest that as further public sector restructuring occurs, particularly in relation to downsizing, women may face further employment disadvantage. Grimshaw (2000) warns that measures seeking to decentralise pay setting in the public sector will adversely affect women's wage relativities, which together with reductions in workforce numbers, will intensify gender inequality.

Wajcman (1998) argues that the difficulty for women to move into management positions relates to the pervasive male cultural norms permeating management. Burton (1991) also argues that cultural factors prevent women moving into management. However, Burton (1991) suggests that the construction of merit as composed of male traits together with employment practices that favour males being recruited into male dominated areas through the propensity of males to hire and promote other males, a process she labelled 'homosocial reproduction', militated against women moving into management positions. Burke and McKeen (1994) offer another explanation that relies on the notion of structural and systemic factors preventing women's progression into management. However, Pocock (1998) argues that women are making inroads into male dominated areas of the labour market and industry sectors.

The literature is clear that at a macro level women and men have different employment and career outcomes in the labour market (Morrison, 1992, Parker and Fagensen, 1994). Some of the most striking examples of the differential access to jobs by gender are in the areas of professional and industry segregation by gender. A general feature of labour markets is the preponderance of jobs and industries that are dominated by either males or females. Gender segregation of employment is contended to be deleterious to the operation of the labour market as it distorts supply side factors (Whitfield and Ross, 1996) and runs counter to notions of merit and employment equity (Pocock and Alexander, 1999, Brown and Ridge, 2002a). McDougall (1998: 72) argues that in the UK public sector employment where females outnumber males, 'vertical and horizontal segregation of women' is a significant and problematic issue. A gender-segregated workforce is argued to create broader problems of an inability to be responsive to demands for different types of skills and generates impediments to flexibility in economic restructuring on a national basis (OECD, 1991).

Gender segregation is argued to have different effects on career progression and employment outcomes in the public sector for males in female dominated agencies compared to females in male dominated agencies (Brown, 2002a, 2002b). In this way, the careers and employment outcomes of men and women may be adversely affected by gender domination of their employing agency.

\section{Methodology}

The methodology employed was based on gathering Equal Employment Opportunity and HRM data from the State Services Commission, New Zealand. Information was sought relating to managerial level and classification in those public sector agencies that were gender dominated.

Gender density of agencies was calculated in accordance with the figure of 60 percent or higher adopted in the Report, Work and Family: State of Play, (Work and Family Unit, W\&FU, 1999). Agencies with a gender density of greater than 60 percent female employees were categorised as 'female dominated' and those agencies employing greater than 60 percent males were classified as 'male dominated'. Only agencies with total employee number of 100 or greater were used. Using the Human Resource Capability Survey 2001 (State Service Commission, 2001), five agencies were categorised as male dominated, 11 agencies were categorised as female dominated and 22 agencies were categorised as gender 
neutral agencies. Table 1 displays the number of male and female employees in each category.

Table 1.

\begin{tabular}{|c|c|c|c|}
\hline Category & $\begin{array}{l}\text { Male } \\
\text { employees } \\
\text { range }\end{array}$ & $\begin{array}{l}\text { Female } \\
\text { employees } \\
\text { range }\end{array}$ & Total \\
\hline Male & 203 to 2712 & 95 to 1376 & 298 to 4088 \\
\hline $\begin{array}{l}\text { Dominate } \\
\text { Female }\end{array}$ & 45 to 1612 & 70 & 121 to 4859 \\
\hline Dominat & & שת & \\
\hline $\begin{array}{l}\text { Gender } \\
\text { Neutral }\end{array}$ & 69 to 496 & 53 to 596 & 142 to 1092 \\
\hline
\end{tabular}

Source: State Service Commission (2001).

Data were collected indicating the numbers of males and females in gender dominated agencies for management tiers, managers, professionals, associate professionals and office clerks for the years 2000 and 2001. Levels of management were classified according to the types of responsibilities undertaken in relation to supervision of staff and strategic advice-giving activities. Tier 3 Management level was the entry level to management and related to those managers with responsibility for formulating programs and polices and having accountability for financial, employment and human resource aspects of a specific work area. Tier 2 Management levels supervise Tier 3 Management. The duties of Tier 2 Managers are of a higher order than Tier 3 Managers in that they are directly responsible for leadership and strategic direction of lower level managers and also support Tier 1 Managers in relation to advanced organisational operations and development. Tier 1 Management is defined as having ultimate control of the organization.

\section{Findings and discussion}

The extent to which equity concerns have translated into equity gains in the New Zealand public sector is examined. In the mid 1990s, it was found that women were significantly underrepresented in management positions in the public sector, men received higher-level salaries, and males were more likely to be appointed at higher than average salaries (Boston et al, 1996). However, it was also found that the percentage of female managers appointed had improved over time rising from 9 percent in 1991 to 20 percent two years later. From a low base at the beginning of the 1990 s, women have been able to make some inroads into the organisational hierarchy and shift into senior management positions in greater numbers. The situation at the beginning of the 2000 s needs revisiting to determine if further changes have occurred. There are three areas of research findings that will be discussed in the paper (see Figure 1). Representation and career progression will be examined in relation to women in employed in male dominated agencies and for women in female dominated agencies.
First, for women in male dominated agencies, the findings indicate that their representation is stable and static with poor outcomes. Second, in relation to women in female dominated agencies, results show an overall improvement in every job category. The final research area investigated the differences between male dominated and female dominated agencies. Agency characteristics identified in the research showed that all agencies were highly female dominated in the clerical classifications but male dominated agencies have significant overrepresentation of males in professional and managerial categories.

A study of the effects of gender segregation in the Australian public sector found there are different outcomes for males in female dominated agencies and females in male dominated agencies due to the dispersion of males across the employment classifications in female dominated agencies and the crowding of females into the lowest classifications in male dominated agencies (Brown, 2002a). While this research has found that women have not been able to make much ground in male dominated agencies, women have achieved better outcomes in female dominated agencies.

Males have still been able to block women's participation in senior management positions in the public sector. As women have moved into public sector employment, they have clustered at the lower ranges of the public sector employment categories. Women occupy around 80 percent of the clerical administrative positions. This pattern appears not to provide women with a career trajectory to senior management, particularly in those agencies overrepresented by males. Similarly, women are not moving through into managerial levels in proportions commensurate with their share of clerical positions, again, specifically in male dominated agencies.

However the type of employment of males and females is also at issue. Males dominate the associate professional categories, in male dominated agencies and women dominate the associate professional categories of female dominated agencies and to a greater extent than males in male dominated agencies. Further research is required to develop an understanding of the reasons for men's high degree of exclusion from these types of jobs in female dominated agencies and women's low representation in these employment categories in male dominated agencies.

For women in female dominated agencies, however there has been improvement in the female share of each job category and management tier. However, there is a stark difference in managerial attainment in male dominated agencies. Little or no progress has been made by women in moving into the more senior management ranks in male dominated agencies. 


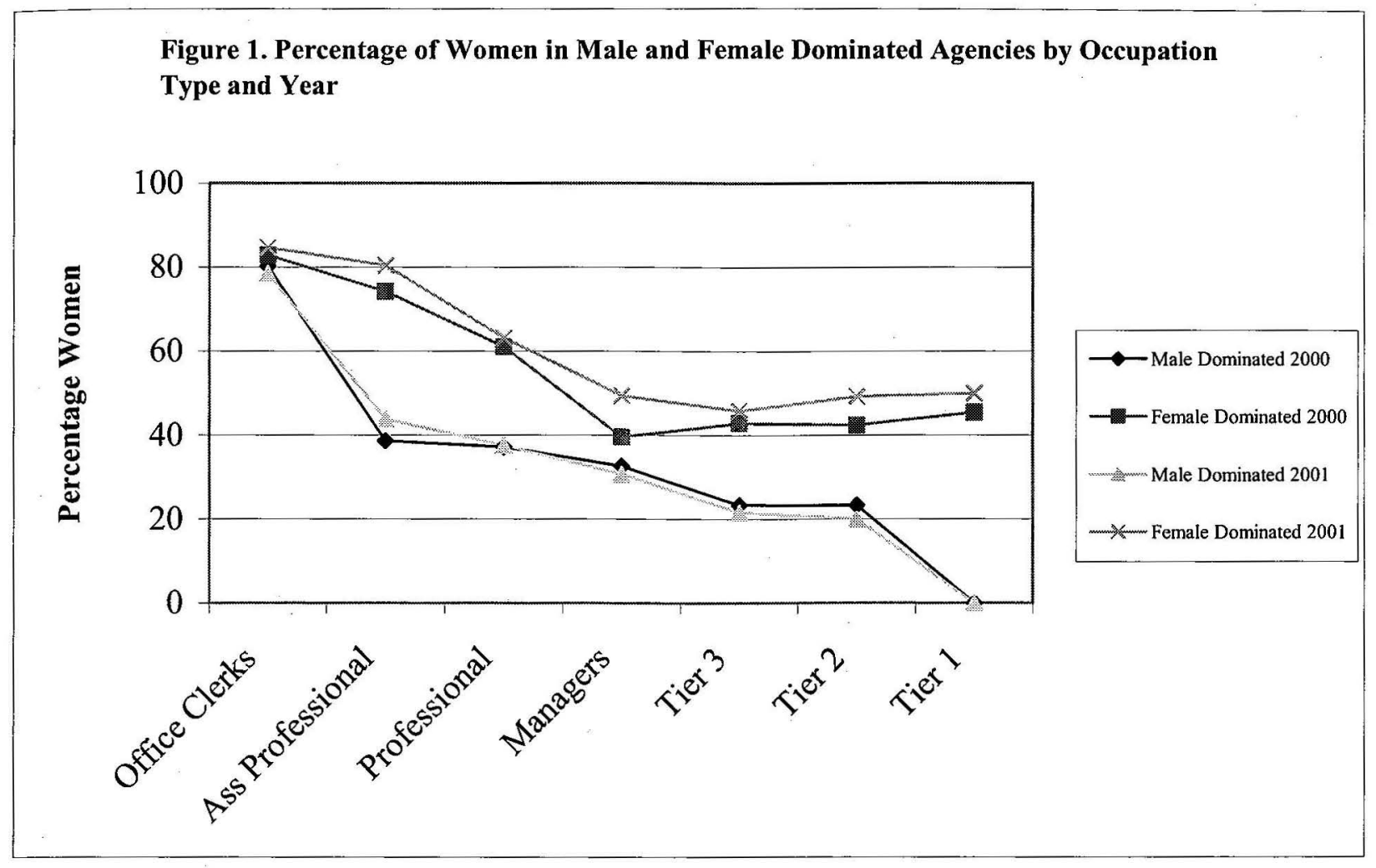

While there is a legislatively mandated requirement for Chief Executive (CE) officers to be a 'good employer' (Boston, et al, 1996), patterns of gender bias persist. Public sector collective agreements retained broad consistency of employment conditions but deregulation resulted in managers attempting to establish individual and direct relationships with public sector staff and the effects were evidenced in managerial pay rises and in the altered structure and makeup of public sector employment (Walsh, 1998). Clerical classifications are over-represented by females in both female dominated and male dominated agencies. Associate professional categories are over-represented by males in male dominated agencies but are over-represented by females in female dominated agencies. The most problematic area is in Tier 1 Management in male dominated agencies in which females have made little progress in moving into senior management positions.

Walsh (1998) suggests that the shift to Chief Executives (CEs) having greater control over recruitment and development of staff has been the most significant feature of the changed environment in the public sector employment relations. It may be the case that male CEs establish a culture of exclusion for women in professional, quasi professional and management positions in male dominated agencies. However, the evidence that women are moving into management in female dominated agencies weakens Wajcman's (1998) contention that management itself is a male domain and has been constructed according to male norms. The domination of males in associate professional employment categories may indicate that Burton's (1991) characterization of 'homosocial reproduction' is a factor in the preponderance of males in professional and managerial positions in male dominated agencies, especially as female dominated agencies also show better outcomes for women in these types of positions.

However, it may also be the case that broader issues are at stake. Associate professional classifications are significantly male dominated in those agencies overrepresented by males and are overwhelmingly female dominated in those agencies over represented by females. This result suggests that differential training and qualifications by men and women may affect career choices in particular professional employment categories. It is suggested that further research is needed to determine whether institutional and structural issues may lie at the base of these differences or whether the results reflect prevailing cultural norms of the different agencies and the individual employment choices of agency CEs and selection panels.

\section{Conclusion}

The question of how changes in public sector management and organization have affected women's employment and career outcomes has been examined. This study utilised EEO and employment data to analyze patterns of career progression and employment profiles in relation to public sector employees. The research examined the effects of gender segregation on careers and 
employment for males and females in both male dominated and female dominated public sector agencies. Findings confirm the general trend for steady improvement in the participation of women in the New Zealand public sector (Boston et al, 1996). In particular, women in female dominated agencies are improving their share of management and professional positions. While the data tests outcomes over a two-year timeframe, it has been found that women have also improved slightly their representation in female dominated agencies over time but women have not been able to shift from their entrenched position in male dominated agencies.

However, there are areas of employment that are shown to warrant attention. Overall, the numbers of women in management and their progression through the levels of management remains problematic. The results of this initial study indicate that domination of public sector agencies creates different patterns of employment and differential opportunities for career progression on a gendered basis. Further research to determine the reasons for the overrepresentation of women in clerical occupations is warranted. In addition, issues surrounding the dominance of professional and semi-professional positions by men in male dominated agencies and women in female dominated agencies would be useful. In this way, barriers to entry to particular employment categories could be determined and the prospects for achieving more equitable employment opportunities and career outcomes for males and females evaluated.

\section{References}

Boston, J., Martin, J., Pallot, J. and Walsh, P. (1996). Public Management: The New Zealand Model. Auckland: Oxford University Press.

Brown, K. and Ridge, S. (2002a). Moving into management: Gender segregation and its effect on managerial attainment. Women in Management Review, 17(7), 318-327.

Brown, K. and Ridge, S. (2002b). Mind the gap: Gender wage differentials in the Australian Public Sector. Equal Opportunities International, 21(3), 1-11.

Brown, K. (1997). Evaluating equity outcomes in state public sectors: A comparison of three housing agencies. Australian Journal of Public Administration, 56(4), 57-66.

Burke, R. and McKeen, C. (1994). Career development among managerial and professional women. In Davidson, M. and Burke, R. (eds), Women in Management: Current Research Issues. London: Paul Chapman Publishing.

Burton, C. (1991). The Promise and the Price. The Struggle for Equal Opportunity in Women's Employment. Sydney: Allen and Unwin.
Gardner. M. and Palmer, G. (1997). Employment Relations. Melbourne: Macmillan, Melbourne.

Gornick, J. and Jacobs, J. (1998). Gender, the welfare sate, and public employment: A comparative study of seven industrialized countries. American Sociological Review, 63, 688-710.

Gregory, R. (1999). Social capital theory and administrative reform: Maintaining ethical probity in Public Service. Public Administration Review, 59(1), 63-75.

Grimshaw, D. (2000). Public sector employment, wage inequality and the gender pay ratio in the UK. International Review of Applied Economics, 14(4), 427-448.

Hoffnar, E. and Greene, M. (1996). Gender discrimination in the public and private sectors: A sample selectivity approach. Journal of SocioEconomics, 25(1), 105-115.

Kramar, R. (1995). Equal employment opportunity: An essential and integral part of good management. In O'Neill, G. and Kramar, R (eds), Australian Human Resources Management. Melbourne: Pitman.

McDougall, M. (1998). Devolving gender management in the public sector: opportunity or opt-out. International Journal of Public Sector Management, 11(1), 71-80.

Morrison, A. (1992). The New Leaders, San Francisco: Jossey-Bass.

OECD (1991). Shaping Structural Change: the Role of Women. Paris: OECD.

Parker, B. and Fagensen, E. (1994). An introductory overview of women in corproate management. In Davidson, M. and Burke, R. (eds), Women in Management: Current Research Issues. London: Paul Chapman Publishing.

Pocock, B. and Alexander, M. (1999). The price of feminised jobs: New evidence on the gender pay gap in Australia. Labour \& Industry, 10(2), 75100.

Pocock, B. (1998). All change, still gendered: The Australian labour market in the 1990s. Journal of Industrial Relations, 40(4), 580-603.

Quiggan, J. (1998). Social democracy and market reform in Australia and New Zealand. Oxford Review of Economic Policy, 14(1), 76-95.

Sawer, M. (1999). The watchers within: women and the Australian state. In Hancock, L. (ed) Women, Public Policy and the State. South Yarra: Macmillan, pp. 36-53. 
Schwartz, H. (1994). Public choice theory and public choices: Bureaucrats, and state reorganization in Australia, Denmark, New Zealand, and Sweden in the 1980s. Administration \& Society, 26(1), 48-77.

State Services Commission (2001). Human resources Capability Survey 2001. Wellington: State Services Commission.

Van Acker, E. (2001). Women's policy activism and changing relations with the state. In Davis, G. and Weller, P. (eds), Are You Being Served? State, Citizens and Governance. Sydney: Allen \& Unwin.

Wajcman, J. 1998. Managing Like a Man: Women and Men in Corporate Management. Cambridge: Polity Press.

Wallis, J. and Dollery, B. (2001). Government failure, Social Capital and the Appropriateness of the New Zealand Model for Public Sector reform in
Developing Countries. World Development, 29(2), 245-263.

Walsh, P. (1998). From Uniformity to Diversity? Reinventing Public Sector Industrial Relations in New Zealand. Australian Journal of Public Administration, 57(2), 55-60.

Wanna, J., O'Faircheallaigh, C. and Weller, P. (1992). Public Sector Management in Australia. South Melbourne: Macmillan.

Whitfield, K. and Ross, R. (1996). The Australian Labour Market. Sydney: Harper Educational.

Work and Family Unit (1999). Work and Family: State of Play. Canberra: Department of Employment, Workplace Relations, and Small Business, AGPS.

Yeatman, A. (1993) Corporate management and the shift from the welfare to the competition state. Discourse, 13(2), 3-9. 